\title{
ECOLOGICAL CONSEQUENCES OF CHANGING FUELWOOD CONSUMPTION PATTERNS IN REMOTE VILLAGES OF NORTHWESTERN CHINA
}

\author{
PAN, Y. ${ }^{1}-$ ZHEN, L. ${ }^{1}{ }^{*}-$ YANG, L. ${ }^{1,2}-$ Helming, K. ${ }^{3}-$ KOENIG, H. ${ }^{3}-\mathrm{CAO}, \mathrm{X} .{ }^{1,2}-\mathrm{LI}, \mathrm{F}^{1}{ }^{1}-$ \\ WEI, Y. ${ }^{1,2}-$ LIU, $X^{1,2}-$ LONG, $X^{1,2}$ \\ ${ }^{1}$ Institute of Geographic Sciences and Natural Resources Research, \\ Chinese Academy of Sciences, 11A Datun Road, Chaoyang District, Beijing 100101, China \\ e-mail: panying@igsnrr.ac.cn \\ ${ }^{2}$ Graduate School of Chinese Academy of Sciences, \\ 19A Yuquan Road, Beijing 100049, China \\ ${ }^{3}$ Leibniz-Centre for Agricultural Landscape Research, \\ Eberswalder Strasse 84, D-15374 Müncheberg, Germany \\ (phone: +86-10-6488-8155; fax: +86-10-6485-1844) \\ *Corresponding author \\ e-mail: zhenl@igsnrr.ac.cn \\ (Received $29^{\text {th }}$ September 2011; accepted $10^{\text {th }}$ February 2012)
}

\begin{abstract}
Consumption of ecosystem goods and services is the foundation of coupled human-natural systems. This paper reported the change in fuelwood consumption in remote northwestern Chinese villages and the ecological consequences that have occurred as a result of the Sloping Land Conversion Program (SLCP), one of China's biggest ecological restoration programs. We conducted this study using structured questionnaires that collected data on fuelwood consumption in 1999 and 2008. For these villages, fuelwood was the most important fuel source (84\% of total fuel consumption in 1999). The SLCP restricted cutting of forests, so fuelwood consumption decreased to 39\% of the 1999 total by 2008. In response to this decrease and increased planting of trees, the forest area increased. However, a spatial imbalance in fuelwood consumption persisted; the remaining demand for fuelwood meant that forests near villages were under high pressure, with harvesting often exceeding the natural productivity. To meet the demand for fuel and replace the fuelwood, coal consumption increased by $562 \%$. The switch from fuelwood to coal increased $\mathrm{CO}_{2}$ emissions by $339 \%$ from 1999 to 2008 . These results have clear consequences for the region's ecology and suggest the need to take measures to account for the consequences of the SLCP.
\end{abstract}

Keywords: Ecological consequences; Fuelwood; Fuel consumption; Sloping Land Conversion Program; Northwestern China

\section{Introduction}

Consumption of ecosystem goods and services is a key factor in coupled humannatural systems (J. Liu et al., 2007; Zhen et al., 2010b). The steady increase in human activities and consumption of ecosystem services has led to degradation of around $60 \%$ of the world's ecosystems (MEA, 2005), accompanied by a 30\% increase in atmospheric $\mathrm{CO}_{2}$ level (Vitousek et al., 1997). The consumption of ecosystem services has exceeded the productive capacity of world's ecosystems by as much as $50 \%$ (WWF, 2010). However, the share of the biosphere's resources and ecosystem services consumed by humanity will continue to increase. 
Differences and changes in consumption patterns will have different consequences for human-environment systems. For example, many case studies have shown obvious differences in food consumption patterns between China and other countries, leading to different ecological consequences (Gerbens-Leenes and Nonhebel, 2005; GerbensLeenes et al., 2010; Zhen et al., 2010a, 2010b). The increasing consumption of beverages and foods of animal origin is likely to create additional pressure on natural resources, especially in Asia (Gerbens-Leenes et al., 2010), as well as the loss and fragmentation of native forests (McAlpine et al., 2009) and additional emissions of greenhouse gases (Fearnside, 2005; McAlpine et al., 2009).

Fuelwood consumption is a particularly important problem, since approximately half of the world's population uses fuelwood in their daily lives (He et al., 2009). Fuelwood collection has been recognized as an important factor in habitat fragmentation and biodiversity loss (Bearer et al., 2008; He et al., 2009; J. Liu et al., 1999). For instance, the increased population and fuelwood collection intensities in China's Wolong National Nature Reserve have dramatically decreased the forest habitat that sustains populations of the giant panda (Ailuropoda melanoleuca) (J. Liu et al., 1999). As fuelwood becomes more difficult to find and collection sites move higher in elevation and become more remote, the high-quality panda habitats face an increasing risk of fragmentation and degradation (He et al., 2009). However, fuelwood consumption that does not exceed the natural growth rate of the forest could potentially decrease net $\mathrm{CO}_{2}$ emissions if fuelwood replaces the consumption of fossil fuels (Eriksson and Gustavsson, 2010). A potential reduction of from 2 to $30 \%$ has been estimated for various European countries (Schwaiger and Schlamadinger, 1998). This suggests that sustainable use of fuelwood may represent a good option to reduce the environmental impacts of energy production.

National policies affect human activities and the resulting consumption of ecosystem services, with related ecological consequences. The "greening" of global consumption patterns by deliberate development or modification of policies is an important goal (Spaargaren and Mol, 2008). In this context, many scientists have studied the impact of such policies on ecosystem services in coupled human-natural systems. For example, to prevent further habitat degradation and restore panda habitat, the Chinese government implement several conservation policies (J. Liu et al., 2007). These policies prohibited the development of cropland in forested areas, limited the sites where fuelwood can be harvested and the amount of fuelwood that can be harvested from these sites, but the effects appear to have been imperfect (Chen et al., 2009). Adjusting the conservation policies to provide payments to compensate people for conservation costs, increasing job availability in cities, and encouraging the migration of young people to cities appear to have been more helpful (Chen et al., 2009; J. Liu et al., 1999). A recent study on the Mongolian Plateau concluded that different land-use policies, and particularly changes in land ownership, caused major differences in food and fuel consumption by herders in Mongolia and China's Inner Mongolia autonomous region (Zhen et al., 2010b). And traditional nomadic grazing pattern under public land ownership in Mongolia leaded to less degradation in rangeland quality, comparing to the concentrated and continuous herding pressure on the small patches of grassland managed by individual households, under the grassland household contracting policy (Zhen et al., 2010b).

In rural areas of northwestern China, fuelwood is a major fuel for heating and cooking. In recent years, fuelwood consumption has varied greatly as a result of socioeconomic development and policy changes. One major policy that has affected lives in this region is the Sloping Land Conversion Program (SLCP, also known as the 
"Grain for Green Program"), which is one of the largest ecological restoration programs in the world. Under this program, farmers who convert cropland on steep slopes to forest and grassland are rewarded with grain and cash subsidies from the government (J. Liu et al., 2008). The SLCP was originally planned to continue from 2001 to 2010, with a goal of converting $14.63 \times 10^{6}$ ha of sloping farmlands, including $4.4 \times 10^{6}$ ha on slopes steeper than $25^{\circ}$ and in desertified fields. In addition, the program's goal was to afforest or revegetate another $17.33 \times 10^{6}$ ha of sparsely vegetated mountainous, hilly, and eroded lands (Yin and Yin, 2010).

The primary trade-offs for ecosystem services that the policy-makers considered were the need to preserve the food supply of local peoples, while improving soil and water conservation. Research has shown that the SLCP achieved great successes in terms of reducing surface runoff and soil erosion, maintaining soil fertility, and lowering river sediment loads, while conserving water resources and reducing desertification (J. Liu et al., 2008). In addition, the program has promoted socioeconomic development that has helped numerous farmers change their income structure, thereby increasing their income (J. Liu et al., 2008; Uchida et al., 2005; Xie et al., 2006). The subsidy program focused on grain and cash because the primary consumption targeted by the SLCP was food consumption. However, the SLCP also affected the ecosystem service of fuelwood supply due to the increased forest area, and affected fuelwood consumption due to the change in forest management (i.e., increased restrictions on use of the forests).

Unfortunately, there have been no studies of the changes in fuelwood consumption in remote northwestern villages and the associated ecological consequences. The goal of the present study was to provide this information in the context of the SLCP and to discuss the ecological effects of these changes to guide the adjustment of government policies in this remote part of China.

\section{Study area}

This study focused on four villages (Wuzhuang, Xiakou, Sanshilipu, and Shimo) located in Guyuan District of the Ningxia Hui Autonomous Region, a remote mountainous region in northwestern China (Fig. 1). Elevations range from 1248 to 2942 $\mathrm{m}$ above mean sea level, and the region has a continental monsoon climate, characterized by a mean annual rainfall of $472 \mathrm{~mm}$ and an annual average temperature of $9^{\circ} \mathrm{C}$ ranged between -15 to $30^{\circ} \mathrm{C}$ (Zhen et al., 2010a). The long winter ( 4 months) and low temperatures (mean monthly temperatures range from -2 to $-15^{\circ} \mathrm{C}$ ) create a high demand for heating fuel.

As a part of Loess Plateau, this area is sensitive to water and wind erosions due to the special soil characteristics (e.g., loess soil), climatic conditions, and topography. As a result of unsustainable human practices such as excessive cultivation and forest harvesting on slopes, soil erosions has been severe, leading to seriously degraded ecological conditions in many areas (Shi and Shao, 2000). The decades of these activities has intensified and accelerated the ecological degradation, thereby jeopardizing the ecological security of downstream regions of China's Yellow River. The SLCP started in 2000 in this region, with the goal of converting arable land on steep slopes $\left(>15^{\circ}\right)$ into forests and afforesting sparsely vegetated areas of hilly and bare land. The native forests are a mix of broadleaf trees and shrubs, which the shrubs were usually used as fuelwood by local residents. 
In addition to its ecological fragility, this area is home to some of the poorest people in China, with an average total income of 10273.0 RMB (1580.5\$ with currency of 6.5 RMB equal to 1.0 \$) and net income of 2613.9 RMB (402.1\$) in Guyuan District in 2008 , which is much lower than the national average for rural areas. The population density is 140 people per $\mathrm{km}^{2}$, with $86.1 \%$ of the population living in rural areas. The total population increased by $18 \%$ from 1999 to 2008 . However, due to high levels of migration to cities, the rural population only increased by $7 \%$ during this period. There are many villages scattered throughout mountainous areas that lack a transportation infrastructure - some areas lack even basic roads.

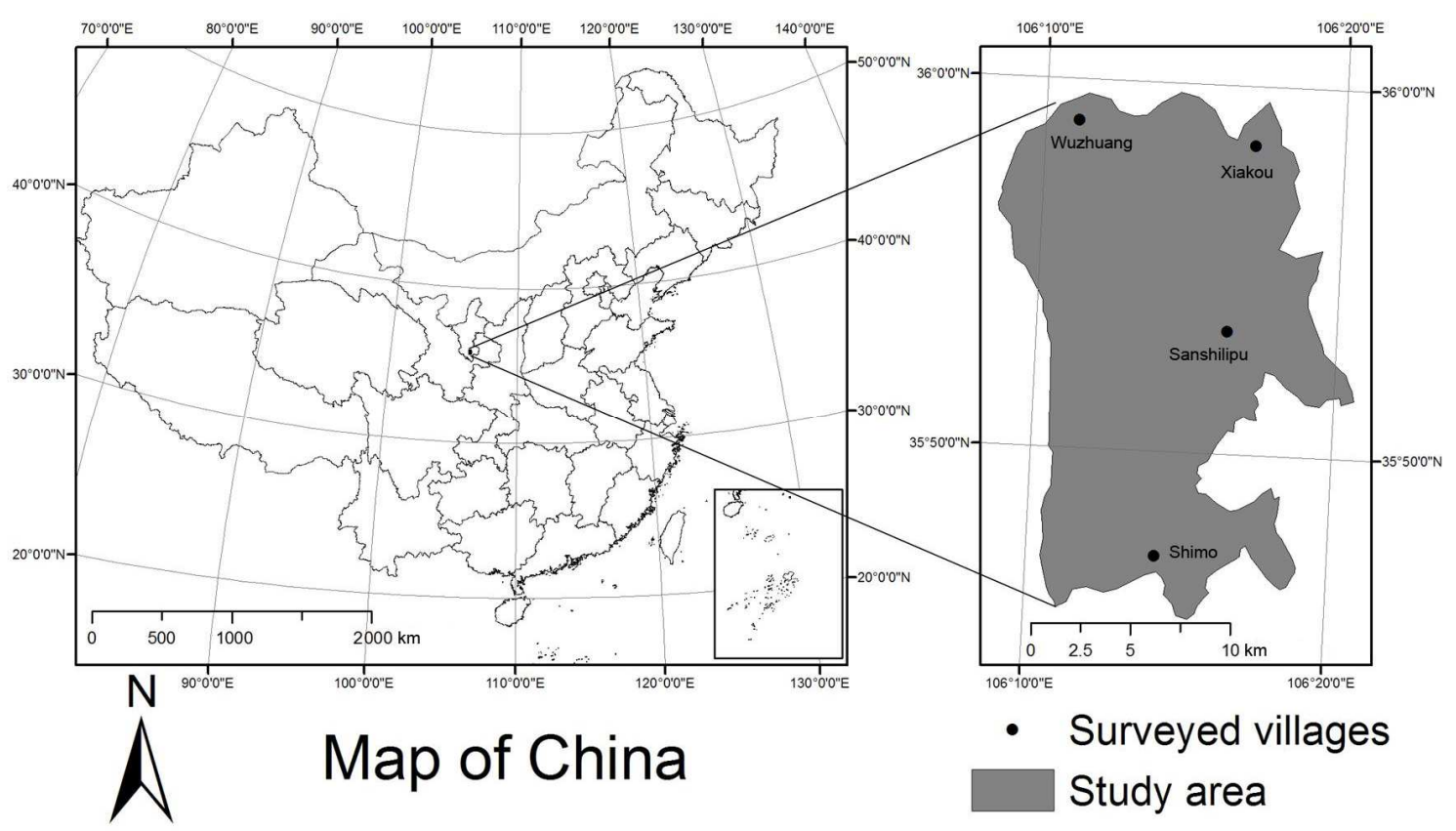

Figure 1. Location of the study area

\section{Research methods and data sources}

\section{Household surveys and data collection}

We conducted a household survey from July to August 2009 using structured questionnaires to obtain our primary data. We randomly selected 208 households in the four villages ( $n=34$ to 77 per village) and interviewed their residents. We asked about the following socioeconomic characteristics of each household: family composition, levels of education, income, and income sources. Our goal was to obtain basic background information on the household. The fuel consumption information we collected included the types, amounts, and distances from home of the market or collection locations. The information on income and fuel consumption was obtained for 1999 and 2008 to provide an indication of changes during this 10-year period. As most of the households had recorded detailed family accounts of their income, fuel consumption, and costs, we believe that despite the potential inaccuracy of this approach, the information we collected provided a good overview of changes in fuel consumption and other characteristics of the families during this period. 
The fuel consumption values were recorded as weights. The distance and associated time cost to reach each fuel market used by the household were recorded. For fuelwood collection, the distance to the typical collection locations and the most distant location were determined for 1999 and 2008, as was the time required to reach these locations and return with fuelwood. The locations of the four villages were also recorded using GPS and input into a GIS program (version 9.3 of ArcGIS, ESRI, Redlands, CA).

Data derived from statistical yearbooks and land-use maps were also used in this paper. The statistical yearbooks include county-level yearbooks produced by the government of Guyuan District and national rural statistics books from 1999 to 2008. Land-use maps of this region were created by interpretation of Landsat TM images by the Data Center for Resources and Environmental Sciences of the Chinese Academy of Sciences (http://www.resdc.cn/english/default.asp). The land-use maps were categorized into six types: arable land, forest, grassland, construction land, water, and bare land.

\section{Data analysis}

The analysis of fuelwood consumption was divided into two parts. First, we analyzed the changes in fuelwood consumption. The consumption data obtained from the interviews were analyzed using Microsoft Excel 2003 and version 10.0 of the SPSS software (SPSS Inc., Chicago, IL). The consumption values for all fuel types were normalized to standard coal equivalents ( $\mathrm{kg} \mathrm{sce}$ ) using the original recorded weight and the conversion factors in the Chinese federal standard (Standardization Administration 2008).

Second, we analyzed the fuelwood collection patterns using our GIS software. The fuelwood collection patterns were demonstrated with an indicator of fuelwood collection intensity. The formula of calculating fuelwood collection intensity is as following:

$$
I_{p}=\sum_{i=1}^{4} \frac{n_{p i}}{n_{\text {total } i}} / 4
$$

$I_{p}$ means the intensity of fuelwood collection from the specific forest of location $p$;

$n_{p i}$ means the amount of households, which the distances from the their village $i$ to the usual fuelwood collection locations are larger than the distance from location $p$ to the village $i$;

$n_{\text {total } i}$ means the total amount of households in village $i$;

$0<I_{p}<1$, where $I_{p}=1$ means all the households from all four villages were usually collecting fuelwood in the forest of location $p$, while $I_{p}=0$ means none of the households did so. To facilitate interpretation of this information, we divided the intensity of fuelwood collection into five classes: very high intensity $\left(0.4<I_{p}<1\right)$ means that $40 \%$ or more of the households usually collected fuelwood in this area, versus $30 \%$ for high intensity $\left(0.3<I_{p}<0.4\right), 20 \%$ for moderate intensity $\left(0.2<I_{p}<0.3\right), 10 \%$ for low intensity $\left(0.1<I_{p}<0.2\right)$ and very low intensity $\left(0<I_{p}<0.1\right)$ means many of the households may have reached that area at some time, but did not usually collect fuelwood there. The distance from each settlement to the most distant fuelwood collection location was assumed to represent the scope of human activity of fuelwood collection for the village. We used the buffer analysis feature provided by ArcInfo to 
determine the boundaries for human activity and for fuelwood collection intensity in each class. In addition to analyzing fuelwood consumption, we examined the possible driving forces responsible for changes in fuelwood consumption based on the consumption and socioeconomic data obtained from our survey.

The analysis of ecological consequences was also divided into two parts. First, we analyzed the forest area and associated net fuelwood productivity changes. The change in forest area was calculated based on the land-use maps from 1999 and 2008. The formula of calculating of net fuelwood productivity was as following:

$$
P_{n}=P_{t}-\mathrm{C}_{t}=A_{f} \times P_{\text {average }}-n_{t} \times C_{\text {average }}
$$

$P_{n}$ means the net fuelwood productivity;

$P_{t}$ means the total fuelwood productivity;

$C_{t}$ means the total fuelwood consumption;

$A_{f}$ means the forest area;

$P_{\text {average }}$ means average natural productivity per hectare per year for the four major shrubs tree species of different age growing in the Guyuan area, which are Amygdalus davidiana, Hippophae rhamnoides, Caragana korshinskii and Caragana microphylla (X.L. Liu, 2009);

$n_{t}$ means the total amount of households;

$C_{\text {average }}$ means the average fuelwood consumption per household;

We assumed that 40,30,20, and $10 \%$ of the fuelwood consumption was supplied by the forests with very high, high, moderate, and low fuelwood consumption intensities, respectively. The net fuelwood productivity $\left(P_{n}\right)$ was calculated respectively in the forest with each estimated fuelwood collection intensity level. Net productivity was assumed to represent the threshold for potential ecological degradation of the forest, which would occur when fuelwood was harvested at a rate exceeding the forest's natural growth rate (Ghilardi et al., 2009).

We also calculated the estimated emissions of greenhouse gases resulting from the consumption of different types of fuel using the associated emission factors. The fuelwood use was considered to be carbon-neutral, yet would still release gases such as carbon dioxide $\left(\mathrm{CO}_{2}\right)$, methane $\left(\mathrm{CH}_{4}\right)$, and nitrous oxide $\left(\mathrm{N}_{2} \mathrm{O}\right)$, particularly if the combustion is incomplete for the latter two gases (Bhattacharya and Abdul Salam, 2002; Schwaiger and Schlamadinger, 1998). We considered the emissions of $\mathrm{CH}_{4}$ and $\mathrm{N}_{2} \mathrm{O}$ due to fuelwood consumption using the associated emission factors for cooking and heating provided by Bhattacharya and Abdul Salam (2002). The emission factors for $\mathrm{CO}_{2}, \mathrm{CH}_{4}$, and $\mathrm{N}_{2} \mathrm{O}$ from coal and liquefied petroleum gas (LPG) were obtained from IPCC (2006). The $\mathrm{CH}_{4}$ and $\mathrm{N}_{2} \mathrm{O}$ emissions were converted into $\mathrm{CO}_{2}$ equivalents based on their global warming potential (IPCC, 2006). All total $\mathrm{CO}_{2}$ emissons reported in this paper represent the sum of actual $\mathrm{CO}_{2}$ emissions and the equivalent $\mathrm{CO}_{2}$ emissions from $\mathrm{CH}_{4}$ and $\mathrm{N}_{2} \mathrm{O}$.

\section{Results}

\section{Patterns of and changes in fuelwood consumption}

We calculated the average consumption per household of different types of fuel for the four villages based on the survey data. Our survey revealed that the fuel types 
consumed in the villages included fuelwood, dry grass, straw, animal dung, coal, LPG, and electricity. As the consumption of animal dung in the four villages was limited (less than $1 \%$ ) and wasn't recorded in national statistics, we excluded the animal dung from the rest of our analysis. Similarly, electricity did not become a significant source of power to the four villages before 2008, so we have not discussed the impact of electricity. We also combined the data for dry grass and straw, since they are recorded as a single category in national statistics and because our focus was on fuelwood rather then on fine distinctions within fuel categories.

Fuelwood was the most important type of fuel in 1999, accounting for $84 \%$ of the total fuel consumption (Fig. 2). By 2008, the total fuel consumption per household had decreased by $13.6 \%$. The structure of the fuel consumption also changed. Biomass fuel (wood, grass, and straw) decreased from $91.3 \%$ of the total in 1999 to $41.9 \%$ in 2008 , and fossil fuels (coal, LPG and electricity from coal-fired power plants) increased from $8.7 \%$ of the total to $58.1 \%$ during the same period. This change mainly resulted from a decrease in fuelwood consumption per household, from $1518.1 \mathrm{~kg}$ sce in 1999 to 593.4 $\mathrm{kg}$ sce (i.e., to $39 \%$ of the 1999 level), whereas coal consumption per household increased from $144.7 \mathrm{~kg}$ sce to $813.4 \mathrm{~kg}$ sce (i.e., to $562 \%$ of the 1999 level).

Northwestern China is less developed than other regions of China. Compared with the national averages, the fuel consumption and patterns of change were therefore different. First, residents of the remote northwestern villages consumed more fuels than the national rural average, by around $18 \%$ in 1999 and $7 \%$ in 2008, mainly due to the long and cold winter. Second, residents of the remote northwestern villages preferred biomass fuels (fuelwood, dry grass and straw), which accounted for more than $90 \%$ of the total fuel consumption in 1999, versus a national rural average of only about $50 \%$. The national rural average for fuelwood consumption accounted for around $20 \%$ of the total fuel consumption, and remained stable from 1999 to 2008, but coal consumption decreased by two-thirds, accounting for only $11 \%$ of the total in 2008. In contrast, with decreasing fuelwood consumption, coal consumption in the remote northwestern villages has increased greatly, and accounted for more than half of the total fuel consumption in 2008.

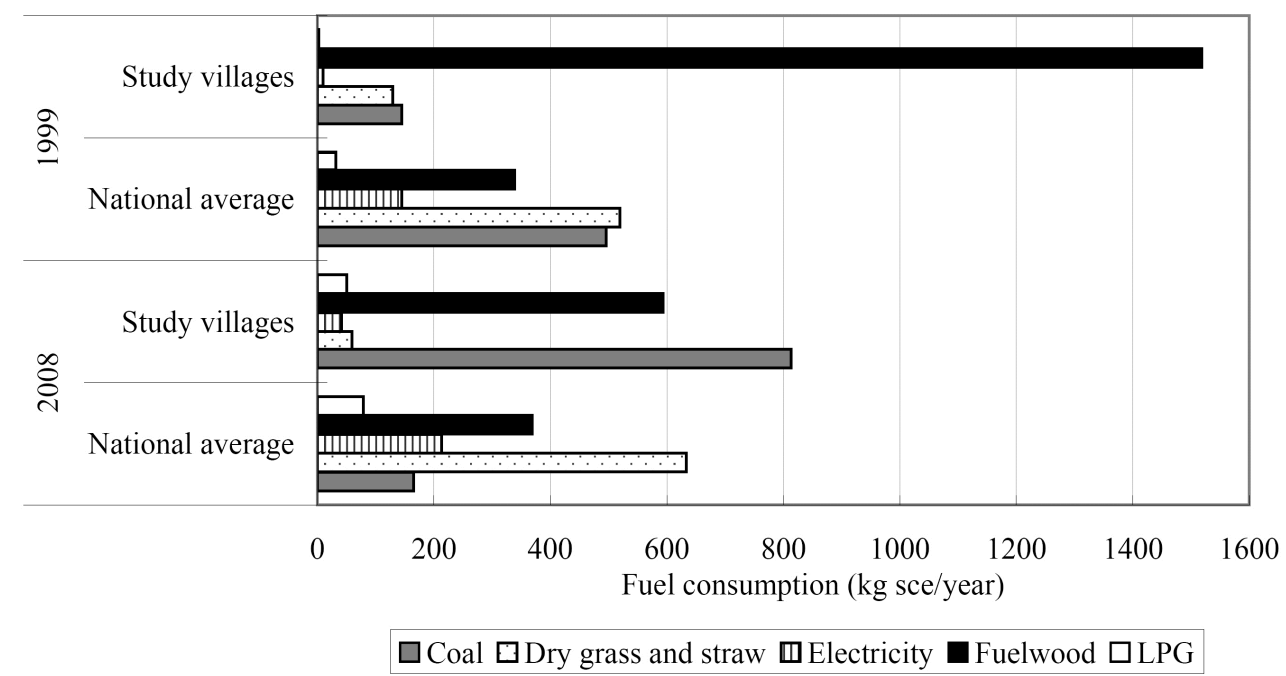

Figure 2. Structure of and changes in fuel consumption in four remote villages in northwestern China and national rural averages. (sce, standard coal equivalent) 


\section{Changes in fuelwood collection patterns}

Villagers in the study villages collected fuelwood in a traditional way. They traveled by foot to collect the fuelwood and transported the fuelwood to their homes on their back, which is hard work. Normally, most villagers indicated that they preferred to go to nearby forests to collect fuelwood, as long as wood was available. However, due to the SLCP policy, $46.7 \%$ of the forest in this area was closed to human uses in 2000, and people were forbidden to harvest wood. The villagers were allowed to enter other parts of the forest, but were forbidden to cut the branches of live trees; they were only allowed to collect dead wood from the ground. Thus, some villagers chose to harvest branches illegally or sneak into the close forest, others chose to go farther to collect.

For the four villages as a whole, the average distance to the fuelwood collection locations was $2.92 \mathrm{~km}$ in 1999. In 2008, this distance had decreased to $2.58 \mathrm{~km}$. This decreased average distance coincides with the decrease in average fuelwood consumption from 1999 to 2008 (Fig. 2). The fuelwood collection intensity from distant forests decreased, but the forests near the villages sustained a very high fuelwood collection intensity because fuelwood demand remained high.

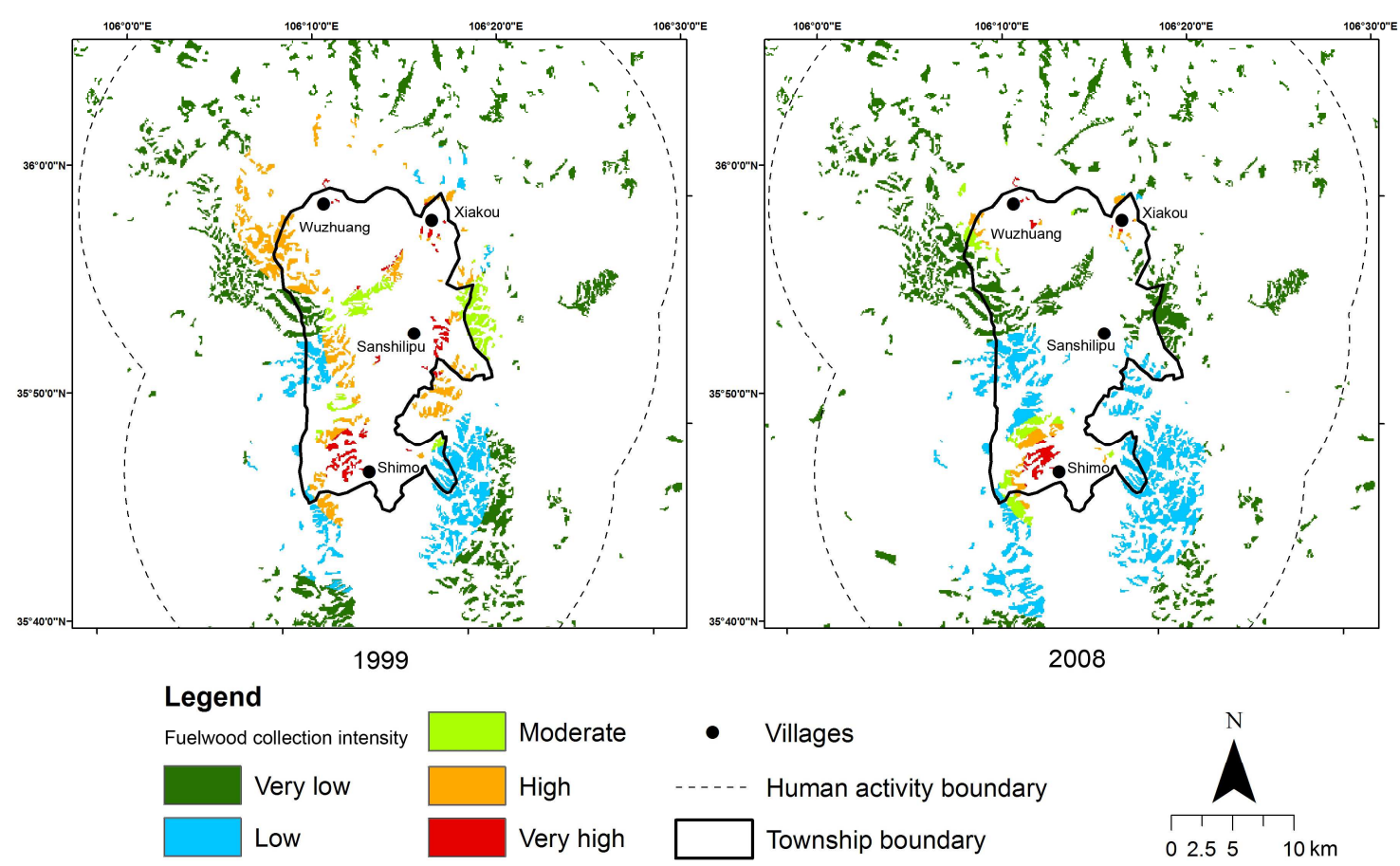

Figure 3. Patterns and changes in fuelwood collection intensity from 1999 to 2008

The average distances to the fuelwood collection locations varied among the villages, with different patterns of change from 1999 to 2008. For the villages of Wuzhuang, Xiakou, and Sanshilipu, the average distance decreased from 3.0 to $2.6 \mathrm{~km}, 1.9$ to 1.2 $\mathrm{km}$, and 2.9 to $2.4 \mathrm{~km}$, respectively. The areas with very high, high, and moderate fuelwood collection intensity around these villages also decreased to different degrees (Fig. 3). The fuelwood collection intensity decreased from very high to very low in 144 ha of forest, from high to very low in 1581 ha of forest, from high to low in 924 ha of forest, and from moderate to very low in 1226 ha of forest around these villages. The decreasing fuelwood collection intensity coincided with the decrease in average fuelwood consumption per household, which decreased to $20.6,9$, and $66.6 \%$ of the 
total for Wuzhuang, Xiakou, and Sanshilipu, respectively. For Shimo village, the fuelwood consumption also decreased (to $64.5 \%$ of the total), but the average distance to the fuelwood collection locations increased from 3.2 to $3.4 \mathrm{~km}$. The area with low fuelwood collection intensity increased from 3615 ha to 6079 ha. This change means that about $10 \%$ of the households in Shimo village had to travel farther to collect enough fuelwood, but that they still consumed less fuelwood than in 1999.

\section{Driving factors for changes in fuelwood consumption}

Income was one of the main factors that affected fuelwood consumption. We divided the households into six groups according to their total income in 2008. The average total income (10 $273 \mathrm{RMB}$ ) was lower than in other rural areas of China (Table 1); at the national level, the average total rural income was 23164 RMB per household in 2007. In 1999, total fuel consumption increased with increasing average total household income, from $967 \mathrm{~kg}$ sce at the lowest average total income (2215 RMB) to $4079 \mathrm{~kg}$ sce at the highest average total income (7686 RMB). In 2008, the same relationship existed (Table 1). From 1999 to 2008, the average total income of most households increased, except for the poorest households, whose total income remained less than $3000 \mathrm{RMB}$ in 2008. The income gained from full-time or part-time off-farm employment in towns or cities contributed most to the income increase, as this income accounted for an average of $68 \%$ of the total income in 2008. However, for most households, total fuel consumption did not increase along with the increase in total income; the total fuel consumption decreased for nearly $50 \%$ of the households with total incomes greater than $12000 \mathrm{RMB}$ in 2008.

Table 1. Fuel consumption patterns of the households as a function of annual household income levels. (sce, standard coal equivalent)

\begin{tabular}{|c|c|c|c|c|c|c|c|}
\hline & & \multicolumn{6}{|c|}{ Total household income in 2008 (RMB) } \\
\hline & & $>20000$ & $\begin{array}{l}12001 \text { to } \\
20000\end{array}$ & $\begin{array}{l}9001 \text { to } \\
12000\end{array}$ & $\begin{array}{l}6001 \text { to } \\
9000\end{array}$ & $\begin{array}{c}3000 \text { to } \\
6000\end{array}$ & $<3000$ \\
\hline \multicolumn{2}{|c|}{ Proportion of the 208 households (\%) } & 7.7 & 16.3 & 19.2 & 21.6 & 19.2 & 15.9 \\
\hline \multirow{2}{*}{$\begin{array}{l}\text { Average total household } \\
\text { income (RMB) }\end{array}$} & 1999 & 7686 & 5726 & 3040 & 3345 & 2588 & 2215 \\
\hline & 2008 & 34675 & 16629 & 10183 & 7676 & 5009 & 1998 \\
\hline \multirow{2}{*}{$\begin{array}{l}\text { Average total fuel } \\
\text { consumption (kg sce) }\end{array}$} & 1999 & 4079 & 3132 & 1553 & 1279 & 1299 & 967 \\
\hline & 2008 & 2419 & 1643 & 1535 & 1589 & 1272 & 1387 \\
\hline \multirow{4}{*}{$\begin{array}{l}\text { Proportion of total fuel } \\
\text { consumption as fuelwood } \\
(\%) \\
\text { Proportion of total fuel } \\
\text { consumption as coal }(\%)\end{array}$} & 1999 & 85.7 & 88.3 & 83.7 & 84.9 & 77.9 & 76.7 \\
\hline & 2008 & 31.0 & 34.7 & 35.5 & 43.1 & 38.4 & 43.5 \\
\hline & 1999 & 3.3 & 8.2 & 8.9 & 10.1 & 9.5 & 9.1 \\
\hline & 2008 & 57.7 & 56.5 & 56.0 & 48.1 & 51.2 & 44.8 \\
\hline \multirow{2}{*}{$\begin{array}{l}\text { Proportion of total fuel } \\
\text { consumption as LPG }(\%)\end{array}$} & 1999 & 0 & 0 & 0.4 & 0 & 0.3 & 0 \\
\hline & 2008 & 7.7 & 3.9 & 2.1 & 4.4 & 1.2 & 0.7 \\
\hline
\end{tabular}

Government policy was an important factor that affected the consumption behavior. In addition to converting arable land on slopes into forest, the SLCP forest management policy forbids the villagers to cut live branches for fuelwood. Thus, for the villagers who still need fuelwood after 2000 legally, they had to travel around more to visit more place collecting dead wood. The time consumed by this travel increased by 127, 191, 122, and 112\% from 1999 to 2008 in Wuzhuang, Xiakou, Sanshilipu, and Shimo 
villages, respectively (Table 2). The increased difficulty of collecting fuelwood led to decreases of fuelwood consumption by 20.6, 9.0, 66.6, and 64.5\% in Wuzhuang, Xiakou, Sanshilipu, and Shimo villages, respectively. However, based on the results in Table 1 , as the mean income increased by $280 \%$, the mean fuel consumption also increased (although the increase was not consistent for all income groups). To fill the gap created by decreased fuelwood consumption and the overall increase in total fuel consumption, all villagers were forced to start purchasing fossil fuel. The mean decrease in fuelwood consumption amounted to $924.7 \mathrm{~kg}$ sce per household from 1999 to 2008; simultaneously, average fossil fuel consumption increased by $717.2 \mathrm{~kg}$ sce. Coal consumption accounted for most of the increased fossil fuel consumption, because the coal was easy to obtain and there were many coal markets near each village. In contrast, there was only one LPG market in the township, and it was far from all four villages. Time consumed in traveling to the coal markets amounted to only 56, 60, 78, and $29 \%$ of the time required to reach the LPG market for villagers in Wuzhuang, Xiakou, Sanshilipu, and Shimo villages, respectively. The price of coal (1260 RMB/kg sce) was also only $38 \%$ of the LPG price (3290 RMB/kg sce) in 2008 . The advance of the coal price was another factor that led the villagers to choose coal to fill the fuel consumption gap caused by their decreased fuelwood consumption.

Table 2. Driving forces responsible for the differences in fuelwood consumption for the individual villages. (sce, standard coal equivalent)

\begin{tabular}{l|c|r|r|r}
\hline & Wuzhuang & Xiakou & Sanshilipu & Shimo \\
\hline Proportion of total fuelwood consumption (\%) & & & & \\
\hline Fuelwood & 22.3 & 9.1 & 56.1 & 58.8 \\
Coal & 60.6 & 69.9 & 38.3 & 30.6 \\
LPG & 0.2 & 15.7 & 0.4 & 0.0 \\
Time consumed (min.) for travel to & & & & \\
Fuelwood collection location in 1999 & 52.2 & 48.5 & 62.3 & 54.2 \\
Fuelwood collection location in 2008 & 66.3 & 92.5 & 75.8 & 60.7 \\
Coal market in 2008 & 18.1 & 19.7 & 25.6 & 24.8 \\
LPG market in 2008 & 32.5 & 32.9 & 32.7 & 86.5 \\
\hline
\end{tabular}

\section{Ecological consequences of the changes in forest area and net fuelwood productivity}

The change in fuelwood consumption had direct impacts on the region's forests. We analyzed the changes in forest area and net fuelwood productivity as a function of the scope of human activities (Fig. 3) using land-use maps and statistical data. As a result of the SLCP, the area of forests increased by 2100 ha from 1999 to 2008 (Table 3). Of this total, $83 \%$ of the forest resulted from conversion of arable land and 17\% resulted from planting trees on bare land. Only $2 \%$ of the newly planted trees were fuelwood forests based on government statistics collected from 2000 to 2008. The forest area under different fuelwood collection intensities also changed greatly during this period. From 1999 to 2008, the areas of forest under very high, high, and moderate fuelwood collection intensity decreased by 57,20 , and $64 \%$, respectively. The areas of forest with low and very low fuelwood collection intensity increased by 184 and $118 \%$, respectively (Table 3).

The total net fuelwood productivity in the study area increased by $25.8 \%$ from 1999 to 2008 due to increased forest productivity and decreased fuelwood consumption. 
Excluding forest with a very low fuelwood collection intensity, the remaining forest had a total fuelwood productivity of 43.9 and $41.4 \mathrm{kt}$ in 1999 and 2008, respectively, versus only 21.7 and 9 kt of fuelwood consumption. Thus, in both 1999 and 2008, the forest could supply more fuelwood than required by the consumption demand. However, due to the spatial imbalance between fuelwood availability and proximity to a village, there was $5.4 \mathrm{kt}$ of overextraction of fuelwood in 700 ha of forest surrounding the villages in 1999. In 2008, this overextraction decreased, but there was still overextraction of $1.9 \mathrm{kt}$ of fuelwood in 400 ha of forest surrounding the villages (Table 3). The forests that were under very high fuelwood collection intensity therefore face a serious risk of degradation.

Table 3. Changes in forest area and productivity from 1999 to 2008 in forests with different fuelwood collection intensities

\begin{tabular}{l|r|r|l|r|l|l|l|r}
\hline & \multicolumn{2}{|l|}{$\begin{array}{l}\text { Area of forest } \\
\text { (thousand ha) }\end{array}$} & \multicolumn{2}{l|}{$\begin{array}{l}\text { Fuelwood } \\
\text { productivity (kt/ } \\
\text { year) }\end{array}$} & \multicolumn{2}{l|}{$\begin{array}{l}\text { Consumption } \\
\text { demand on the } \\
\text { forest (kt) }\end{array}$} & \multicolumn{2}{l}{$\begin{array}{l}\text { Net productivity } \\
\text { (kt/year) }\end{array}$} \\
\hline & \multicolumn{1}{|c|}{1999} & 2008 & 1999 & 2008 & 1999 & 2008 & 1999 & 2008 \\
\hline Fuelwood & & & & & & & & \\
collection intensity & & & & & & & & \\
\hline Very low & 13.8 & 16.3 & 63.7 & 75.5 & 0 & 0 & 63.7 & 75.5 \\
Low & 3.8 & 7.0 & 17.7 & 32.6 & 2.2 & 0.9 & 15.5 & 31.7 \\
Moderate & 1.4 & 0.9 & 6.6 & 4.0 & 4.3 & 1.8 & 2.3 & 2.2 \\
High & 3.5 & 0.7 & 16.3 & 3.1 & 6.5 & 2.7 & 9.7 & 0.4 \\
$\quad$ Very high & 0.7 & 0.4 & 3.3 & 1.7 & 8.7 & 3.6 & -5.4 & -1.9 \\
\hline Total & 23.2 & 25.3 & 107.6 & 116.9 & 21.7 & 9.0 & 85.8 & 107.9 \\
\hline
\end{tabular}

\section{Ecological consequence of changes in CO2 emissions}

The change in fuelwood consumption directly affected the $\mathrm{CO}_{2}$ emissions from fuelwood. The average fuelwood consumption decreased from 1518.1 to $593.4 \mathrm{~kg}$ sce from 1999 to 2008 , leading to a decrease of $\mathrm{CO}_{2}$ emission by $290.1 \mathrm{~kg}$ per household (Table 4). However, the decreased fuelwood consumption was compensated for by increased consumption of other fuel types, particularly coal, indirectly changing $\mathrm{CO}_{2}$ emissions. Coal consumption increased from $144.7 \mathrm{~kg}$ sce to $813.4 \mathrm{~kg}$ sce from 1999 to 2008 , leading to an increase of $\mathrm{CO}_{2}$ emissions from $628.4 \mathrm{~kg}$ to $3531.8 \mathrm{~kg}$ per household. The $\mathrm{CO}_{2}$ emissions from increased coal consumption were greater than the reduction in $\mathrm{CO}_{2}$ emissions caused by decreased fuelwood consumption. For an average household, $668.7 \mathrm{~kg}$ sce of fuelwood consumption was replaced by coal consumption, causing a net increase of $\mathrm{CO}_{2}$ emissions by $2693.6 \mathrm{~kg}$ from 1999 to 2008; this is equivalent to the release of 4 more $\mathrm{kg}$ of $\mathrm{CO}_{2}$ per $1 \mathrm{~kg}$ sce when fuelwood consumption was replaced by coal consumption. 
Table 4. Changes in emission of greenhouse gases due to the changes in fuelwood consumption. (sce, standard coal equivalent)

\begin{tabular}{|c|c|c|c|c|c|c|c|c|c|c|}
\hline & \multicolumn{3}{|c|}{$\begin{array}{l}\text { Emission factors } \\
\qquad(\mathrm{g} / \mathrm{kg})\end{array}$} & \multicolumn{3}{|c|}{$\begin{array}{l}\text { Global warming } \\
\text { potential (GWP) }\end{array}$} & \multicolumn{2}{|c|}{$\begin{array}{l}\text { Consumption per } \\
\text { household } \\
\text { (kg sce) }\end{array}$} & \multicolumn{2}{|c|}{$\begin{array}{c}\mathrm{CO}_{2} \text { emissions per } \\
\text { household } \\
(\mathrm{kg})\end{array}$} \\
\hline & $\mathrm{CH}_{4}$ & $\mathrm{~N}_{2} \mathrm{O}$ & $\mathrm{CO}_{2}$ & $\mathrm{CH}_{4}$ & $\mathrm{~N}_{2} \mathrm{O}$ & $\mathrm{CO}_{2}$ & 1999 & 2008 & 1999 & 2008 \\
\hline Fuelwood & 6.76 & 0.08 & 0 & 23 & 296 & 1 & 1518.1 & 593.4 & 476.3 & 186.2 \\
\hline Coal & 0.031 & 0.047 & 3086.7 & 23 & 296 & 1 & 144.7 & 813.4 & 628.4 & 3531.8 \\
\hline LPG & 0.015 & 0.0015 & 964.1 & 23 & 296 & 1 & 2.0 & 50.5 & 1.1 & 28.4 \\
\hline Overall & & & & & & & 1664.8 & 1457.3 & 1105.8 & 3746.4 \\
\hline
\end{tabular}

Some households used LPG to replace fuelwood consumption. Despite the higher $\mathrm{CO}_{2}$ emission from LPG than from fuelwood, the replacement of fuelwood by LPG only increased $\mathrm{CO}_{2}$ emission by $0.2 \mathrm{~kg}$ per $\mathrm{kg}$ sce, which was much lower than for coal. However, based on our analysis of Table 2, the cheaper prices (by 38\%) and reduced time required to reach the markets (by 56\%) for coal compared with LPG led most households to choose coal rather than LPG to replace fuelwood. On average, only 48.5 $\mathrm{kg}$ sce per household of fuelwood consumption was replaced by LPG, which amounts to around $7 \%$ of the fuelwood consumption replaced by coal (Table 4).

From 1999 to 2008, despite a decrease of average total fuel consumption per household to $87.5 \%$ of the 1999 value, the $\mathrm{CO}_{2}$ emissions per household increased greatly (to $339 \%$ of the 1999 value). This tremendous increase in $\mathrm{CO}_{2}$ emission mainly resulted from decreased fuelwood consumption and increased coal consumption.

\section{Discussion}

The residents of the four remote villages in northwestern China depended greatly on the ecosystem service of fuelwood supply from the forest in their daily lives due to their low income levels and the region's long, cold winter. Villagers chose their fuels mainly based on cost, although the travel time to obtain the fuel was also a factor. Because fuelwood was free, it was the preferred choice. However, after the SLCP began, villagers were forbidden to cut live branches or enter closed forest areas, making fuelwood more difficult to obtain. Some villagers continued to illegally harvest branches because they required the free fuelwood for survival. To prevent implementation of the SLCP from harming local people, the government encouraged workers to change from agriculture to various industries. By 2008, 8 years after the implementation of the SLCP, many villages had successfully shifted from traditional farming to other activities, mainly construction, transportation, and the restaurant business (Uchida et al., 2007; J. Liu et al., 2008). As the difficulty of and time consumed by fuelwood collection increased, most villagers started to purchase fossil fuels to save time that they could use for part-time work. Because of its much lower price and greater availability than LPG, coal was the preferred choice to replace fuelwood. However, as Table 4 shows, decreased fuelwood consumption and its replacement by coal consumption had potentially severe ecological consequences.

As the human population and the demands it places on natural resources increase, the increasing consumption of ecosystem services often leads to degradation of the natural systems (WWF, 2010). Conversely, if the consumption of these services can be 
decreased, this should have positive ecological consequences. For example, reduced fuelwood consumption would alleviate habitat fragmentation and the degradation of natural forests (Bearer et al., 2008; Naughton-Treves et al., 2007). However, if we consider consumption of ecosystem services in the context of coupled human-natural systems, direct and indirect ecological consequences are revealed. Most previous studies have reported large and positive ecological consequences from the SLCP, the synergies of many ecosystem services such as soil and water conservation, biodiversity, ecosystem productivity and carbon sequestration (J. Liu et al., 2008; Yin et al., 2010). In our study area, a remote part of northwestern China that is governed by the SLCP policies, the decreased fuelwood consumption was accompanied by increased forest area. However, the fuelwood consumption showed a high spatial imbalance with respect to the location of the new sources of fuelwood. The forests that surround the villages face a risk of degradation because fuelwood consumption exceeded the natural productivity of these forests. In addition, the decreased fuelwood consumption required villagers to purchase substitute fuel (mainly coal). The resulting increase in coal consumption caused by decreased fuelwood consumption led to a large increase in $\mathrm{CO}_{2}$ emissions. Increase of soil and water conservation and other forest ecosystem services might have to tradeoffs with the increase in fuelwood consumption reducing atmospheric $\mathrm{CO}_{2}$ concentration.

Because of the increasing fuel consumption demand and the still strict forest management guidelines, coal consumption is likely to continue increasing based on the results of our study. For the whole area covered by the SLCP, 32.5 million households participated in 20 provinces (Yin and Yin, 2010), with five of the provinces in the northwest. This means that millions of households in northwestern China are experiencing situations similar to those of the households in our study. The potential additional $\mathrm{CO}_{2}$ emissions that will result from the observed changes in fuelwood consumption should not to be ignored by policy-makers. We have two key suggestions that could mitigate these problems. On the one hand, the construction of more infrastructures for LPG markets should be considered and prices of LPG should be subsidized to encourage villagers to choose LPG instead of coal. On the other hand, reforestation should consider introducing and planting more fuelwood forests composed of fast-growing species near the villages to benefit the households that still need fuelwood. However, because such trees tend to have low water-use efficiency, managers should carefully ensure that the trees will not extract more water from the soil than the environment can provide, since this can exacerbate ecosystem degradation (Cao, 2008). It may also be possible to provide support for villagers so they can establish small-scale businesses to transport fuelwood from more distant forests to each village, thereby both improving employment stability and reducing the spatial imbalance in fuelwood availability.

\section{Conclusions}

In this study, we analyzed the changes in fuelwood consumption in four remote villages in northwestern China and the ecological impacts on the forest area, net productivity, and $\mathrm{CO}_{2}$ emissions. We found that:

- The decreased fuelwood consumption between 1999 and 2008 was mainly associated with the SLCP, which started in 2000 in the study area. This program forbids people from cutting live branches for fuelwood, and closed 
nearly half of the forest areas to villagers. These policies made it difficult for the villagers to collect enough fuelwood.

- The consumption of fuelwood decreased greatly from 1999 to 2008. Simultaneously, the fuelwood collection intensity decreased in most of the forests and the scope of the fuelwood collection by most villagers (i.e., the distance they traveled to harvest the fuelwood) decreased from 1999 to 2008. To compensate for the decrease in fuelwood consumption, coal consumption increased greatly.

- The decreased fuelwood consumption was accompanied by an increased area of forest and increased total net fuelwood productivity. However, the demand for fuelwood remained high, so the forests nearest to the villages sustained a very high fuelwood collection intensity that exceeded the natural productivity of the forests, leading to a risk of degradation. The decreased fuelwood consumption also led to increased coal consumption, thereby increasing net $\mathrm{CO}_{2}$ emissions.

Acknowledgements. We thank the journal's anonymous referees and editorial board member for their helpful comments on our manuscript. This research was funded by the National Key Project for Basic Research (973) (no. 2009CB421106); Technical Support Program of the Ministry of Science and Technology of China (no. 2008BAK50B05); and the China-EU corporation Program of Ministry of Science and Technology of China (no: 0813). We are grateful for the support provided by these organizations.

\section{REFERENCES}

[1] Bearer, S., Linderman, M., Huang, J., An, L., He, G., Liu, J. (2008): Effects of fuelwood collection and timber harvesting on giant panda habitat use. - Biological Conservation 141: 385-393.

[2] Bhattacharya, S.C., Abdul Salam, P. (2002): Low greenhouse gas biomass options for cooking in the developing countries. - Biomass and Bioenergy 22: 305-317.

[3] Cao, S.X. (2008): Why large-scale afforestation efforts in China have failed to solve the desertification problem. - Environmental Science \& Technology 42: 1826-1831.

[4] Chen, X., Lupi, F., He, G., Liu, J. (2009): Linking social norms to efficient conservation investment in payments for ecosystem services. - Proceedings of the National Academy of Sciences USA 106: 11812-11817.

[5] Eriksson, L., Gustavsson, L. (2010): Costs, CO2- and primary energy balances of forestfuel recovery systems at different forest productivity. - Biomass and Bioenergy 34: 610619.

[6] Fearnside, P.M. (2005): Deforestation in Brazilian Amazonia: history, rates, and consequences. - Conservation Biology 19: 680-688.

[7] Gerbens-Leenes, W., Nonhebel, S. (2005): Food and land use. The influence of consumption patterns on the use of agricultural resources. - Appetite 45: 24-31.

[8] Gerbens-Leenes, P.W., Nonhebel, S., Krol, M.S. (2010): Food consumption patterns and economic growth. Increasing affluence and the use of natural resources. - Appetite 55: 597-608.

[9] Ghilardi, A., Guerrero, G., Masera, O. (2009): A GIS-based methodology for highlighting fuelwood supply/demand imbalances at the local level: A case study for Central Mexico. - Biomass and Bioenergy 33: 957-972.

[10] He, G., Chen, X., Beaer, S., Colunga, M., Mertig, A., An, L., Zhou, S., Linderman, M., Ouyang, Z., Gage, S., Li, S., Liu, J. (2009): Spatial and temporal patterns of fuelwood 
collection in Wolong Nature Reserve: Implications for panda conservation. - Landscape and Urban Planning 92: 1-9.

[11] IPCC (Intergovernmental Panel on Climate Change) (2006): 2006 IPCC Guidelines for National Greenhouse Gas Inventories. - Prepared by the National Greenhouse Gas Inventories Programme, Eggleston H.S., Buendia L., Miwa K., Ngara T. and Tanabe K. (eds). Institute for Global Environmental Strategies, Kanagawa, Japan.

[12] Liu, J., Dietz, T., Carpenter, S.R., Alberti, M., Folke, C., Moran, E., Pell, A.N., Deadman, P., Kratz, T., Lubchenco, J., Ostrom, E., Ouyang, Z., Provencher, W., Redman, C.L., Schneider, S.H., Taylor, W.W. (2007): Complexity of coupled human and natural systems. - Science 317: 1513-1516.

[13] Liu, J., Li, S., Ouyang, Z., Tam, C., Chen, X. (2008): Ecological and socioeconomic effects of China's policies for ecosystem services. - Proceedings of the National Academy of Sciences USA 105: 9477-9482.

[14] Liu, J., Ouyang, Z., Taylor, W.W., Groop, R., Tan, Y., Zhang, H. (1999): A framework for evaluating the effects of human factors on wildlife habitat: the case of giant pandas. Conservation Biology 13: 1360-1370.

[15] Liu X.L. (2009): Consumption of ecosystem goods and services: with a case study in Jinghe watershed of Northwest China. - Master's thesis, Institute of Geographic Sciences and Natural Resources Research, Chinese Academy of Sciences. Beijing (in Chinese with English abstract).

[16] MEA (Millennium Ecosystem Assessment) (2005): Ecosystems and human well-being: Synthesis. - Island Press, Washington, D.C.

[17] McAlpine, C.A., Etter, A., Fearnside, P.M., Seabrook, L., Laurance, W.F. (2009): Increasing world consumption of beef as a driver of regional and global change: A call for policy action based on evidence from Queensland (Australia), Colombia and Brazil. Global Environmental Change 19: 21-33.

[18] Naughton-Treves, L., Kammen, D.M., Chapman, C. (2007): Burning biodiversity: Woody biomass use by commercial and subsistence groups in western Uganda's forests. Biological Conservation 134: 232-241.

[19] Schwaiger, H., Schlamadinger, B. (1998): The potential of fuelwood to reduce greenhouse gas emissions in Europe. - Biomass and Bioenergy 15: 369-377.

[20] Shi, H., Shao, M. (2000): Soil and water loss from the Loess Plateau in China. - Journal of Arid Environments 45: 9-20.

[21] Spaargaren, G., Mol, A.P.J. (2008): Greening global consumption: Redefining politics and authority. - Global Environmental Change 18(3): 350-359.

[22] Standardization Administration (2008): General principles for calculation of total $\begin{array}{llll}\text { production } & \text { energy } & \text { consumption, } & \text { 2589-2008. }\end{array}$ http://gb.sac.gov.cn/stdlinfo/servlet/com.sac.sacQuery.GjbzcxDetailServlet?std_code=GB /T\%202589-2008

[23] Uchida, E., Xu, J., Rozelle, S. (2005): Grain for Green: cost-effectiveness and sustainability of China's conservation set-aside program. - Land Economics 81: 247-264.

[24] Uchida, E., Xu, J., Xu, Z., Rozelle, S. (2007): Are the poor benefiting from China's land conservation program? - Environment and Development Economics 12: 593-620.

[25] Vitousek, P.M., Mooney, H.A., Lubchenco, J., Melillo, J.M. (1997): Human domination of Earth's ecosystems. - Science 277: 494-499.

[26] WWF (2010): Living planet report: Biodiversity, biocapacity and development. - WWD, Gland, Switzerland.

[27] Xie, C., Zhao, J., Liang, D., Bennett, J., Zhang, L., Dai, G., Wang, X. (2006): Livelihood impacts of the conversion of cropland to forest and grassland program. - Journal of Environmental Planning and Management 49: 555-570.

[28] Yin, R., Yin, G. (2010): China's primary programs of terrestrial ecosystem restoration: initiation, implementation, and challenges. - Environmental Management 45: 429-441. 
[29] Yin, R., Yin, G., Li, L. (2010): Assessing China's ecological restoration programs: what's been done and what remains to be done? - Environmental Management 45: 442-453.

[30] Zhen, L., Cao, S., Cheng, S., Xie, G., Wei, Y., Liu, X., Li, F. (2010a): Arable land requirements based on food consumption patterns: Case study in rural Guyuan District, Western China. - Ecological Economics 69: 1443-1453.

[31] Zhen, L., Ochirbat, B., Lv, Y., Wei, Y.J., Liu, X.L., Chen, J.Q., Yao, Z.J., Li, F. (2010b): Comparing patterns of ecosystem service consumption and perceptions of range management between ethnic herders in Inner Mongolia and Mongolia. - Environmental Research Letters 5: 1-11. 